\title{
An outbreak of forty five cases of Pseudomonas aeruginosa acute endophthalmitis after phacoemulsification
}

\author{
Surto de quarenta e cinco casos de endoftalmite aguda por Pseudomonas aeruginosa após facoemulsificação \\ Ricardo luz leitão Guerra ${ }^{1}$, Bruno de Paula Freitas², Cintia Maria Felix Medrado Parcero², Otacílio de Oliveira Maia Júnior², Roberto Lorens Marback ${ }^{3}$
}

\begin{abstract}
Purpose: To describe an outbreak of Pseudomonas aeruginosa endophthalmitis post cataract surgery. Clinical findings, treatment and outcome are discussed.

Methods: Clinical charts review of forty-five patients treated for endophthalmitis in a two-day period. The patients underwent primary vitrectomy, anterior chamber irrigation and intravitreous antibiotic injection. Cultures from vitreous and anterior chamber samples were performed in all patients.

Results: Forty-five patients (twenty-three men and twenty-two women) were identified. The average age was 71.2 years (range, 56-83 years). The right eye (62\%) was affected more often than the left eye (38\%). The median interval between surgery and endophthalmitis onset was 5.5 days (range, 5-6 days). The visual acuity at the diagnosis was better than 20/40 in one patient (2\%), from 20/40 to 20/200 in one patient (2\%), from 20/400 to counting fingers in two patients (4\%), hand movements in eleven patients (24\%), and light perception in thirty patients (68\%). Pseudomonas aeruginosa was the isolated agent in twenty-six vitreous samples and in three anterior chamber samples. Overall, one patient (2\%) achieved a final visual acuity better than 20/40; eight patients (18\%) achieved a final visual acuity from 20/40 to 20/200; six patients (13\%) achieved a final visual acuity from 20/400 to counting fingers; eleven patients (25\%) achieved a final acuity of hand movements; thirteen patients (29\%) achieved a final acuity of light perception and six (13\%) patients had no light perception at the last examination. None of these eyes underwent evisceration or enucleation in a three-month follow-up period.

Conclusion: Even with all the safety that cataract surgery has achieved, today, endophthalmitis remains a risk and a fearful complication of this procedure. In the present study, it was impossible to identify the source of the outbreak.
\end{abstract}

Keywords: Phacoemulsification/adverse effects; Endophthalmitis/etiology; Pseudomonas aeruginosa; Vitrectomy; Pseudomonas, infections; Equipment contamination

\section{RESUMO}

Objetivo: Descrever surto de endoftalmite por Pseudomonas aeruginosa após facectomia. Os achados clínicos, o tratamento e o resultado são discutidos.

Métodos: Revisão dos prontuários de quarentae cinco pacientes tratados paraendoftalmite em um período de dois dias. Todos os pacientes foram tratados porvitrectomia primária, irrigação da câmara anterior e injeção vítrea de antibióticos. Culturas do vitreo e de amostras de câmara anterior foram realizadas em todos os pacientes.

Resultados: Quarenta e cinco pacientes (23 homens e 22 mulheres) foram identificados. A idade média foi 71,2 anos (variação, 56-83 anos). O olho direito (62\%) foi mais afetado do que o esquerdo (38\%). O intervalo médio entre a cirurgia e a apresentação da endoftalmite foi de 5,5 dias (intervalo de 5-6 dias). A acuidade visual no momento do diagnóstico foi melhor que 20/40 em um paciente (2\%), de 20/40 a 20/200 em um paciente (2\%), de 20/400 para contar dedos em dois pacientes (4\%), movimento de mão em onze pacientes (24\%), percepção de luz em trinta pacientes (68\%). Pseudomonas aeruginosa foio agente isolado em 26 amostras de vítreo e em três amostras da câmara anterior. No geral, um paciente (2\%) obteve acuidade visual final melhor que 20/40, oito pacientes (18\%) obtiveram acuidade visual final de 20/40 a 20/200, seis pacientes (13\%) obtiveram acuidade visual final de 20/400 para contar os dedos; onze pacientes (25\%) obtiveram acuidade visual final de movimento de mäo; treze pacientes (29\%) obtiveram acuidade visual final de percepção de luz e seis (13\%) pacientes não havia percepção luminosa no último exame. Nenhum olho foi submetido à evisceração ou enucleação em três meses de acompanhamento.

Conclusão: Mesmo com toda a segurança da cirurgia de catarata nos dias atuais, endoftalmite permanece um risco e uma complicação temível deste procedimento. No presente estudo não foi possivel identificar a fonte do surto.

Descritores: Facoemulsificação/efeitos adversos; Endoftalmite/etiologia; Pseudomonas aeruginosa; Vitrectomia; Infecções por pseudomonas; Contaminação de equipamentos

\section{INTRODUCTION}

Acute endophthalmitis is the most serious complication of cataract surgery and intraocular lens implantation, with an incidence of $0.07 \%$ to $0.12 \%^{(1)}$. Endophthalmitis occurring within 1 to 14 days postoperatively is classified as acute. The most common cultured organism is Staphylococcus epidermidis, accounting for $60 \%$ to $80 \%$ of cases ${ }^{(1)}$. Gram-negative bacteria are responsible for $6 \%$ to $29 \%$ of cases, however, the rapid progression of infection and their virulence often result in a poor visual outcome despite prompt treatment ${ }^{(2-4)}$.
The most common ocular infection caused by Pseudomonas aeruginosa is contact lens-related keratitis, but it may also cause endophthalmitis ${ }^{(5)}$. Outbreaks of postoperative $P$. aeruginosa endophthalmitis have been described in the literature ${ }^{(6-14)}$. The association with intrinsic contamination of ophthalmic solutions and contaminated instruments or equipment has been reported ${ }^{(6-13)}$.

The purpose of this study is describing an outbreak of Pseudomonas aeruginosa endophthalmitis after cataract surgery, which occurred at one ophthalmological center of Eunapólis city, Bahia, Brazil. Clinical findings, treatment and outcome are discussed.
Submitted for publication: March 12, 2012

Accepted for publication: July 30, 2012

Study carried out at Retina and Vitreous Service, Hospital São Rafael - Fundação Monte Tabor - Salvador (BA) - Brazil.

Physician, Department of Ophthalmology, Hospital São Rafael, Fundação Monte Tabor, Salvador (BA), Brazil.

Physician.

${ }^{3}$ Professor, Department of Ophthalmology, Hospital São Rafael, Fundação Monte Tabor, Salvador

(BA), Brazil.
Funding: No specific financial support was available for this study.

Disclosure of potential conflicts of interest: R.L.L.Guerra, None; B.P.Freitas, None; C.M.F.M.Parcero, None; O.O.Maia Jr, None; R.L.Marback, None.

Correspondence address: Otacilio O. Maia Jr. Retina and Vitreous Service, Department of Ophthatmology. Hospital São Rafael - Fundação Monte Tabor. Av. São Rafael, 2142 - Salvador - BA 41253-190 - Brazil - E-mail: omaiausp@uol.com.br 


\section{METHODS}

A retrospective study based on medical records analysis of fortyfive patients with diagnosis of acute endophthalmitis after cataract surgery performed in two consecutive days at one ophthalmological center of Eunapólis city, Bahia, Brazil, and treated at São Rafael Hospital in a two consecutive day period. All patients underwent phacoemulsification and foldable single piece intraocular lens implantation in the capsular bag. Exclusion criteria were incomplete data or less than a ninety day follow-up period. No patient was excluded from the study. The cases occurred in September, 2009.

The study protocol was approved by the Institutional Ethics Review Board of the São Rafael Hospital- Fundação Monte Tabor (CAAE - 00901112.5.0000.0048), and conducted by the Retina and Vitreous Service of the same institution.

Three vitreoretinal specialists submitted all the patients to ophthalmologic examination. The same specialists collected the data.

Data reviewed included demographic information, affected eye, pertinent systemic medical problems, interval between surgery and onset, signs and symptoms, treatment performed and outcome of visual acuity and eye preservation. The ophthalmologic examination at the ninetieth day after treatment was considered as the last ophthalmological examination.

All patients were treated for endophthalmitis on the day of presentation. Anterior chamber irrigation, administration of intravitreous antibiotics (vancomycin and ceftazidime) and primary vitrectomy were performed in all the patients. Secondary vitrectomy (reoperation) was performed in the cases with poor response to the treatment. Perioperative images of different patients are shown in figure 1.

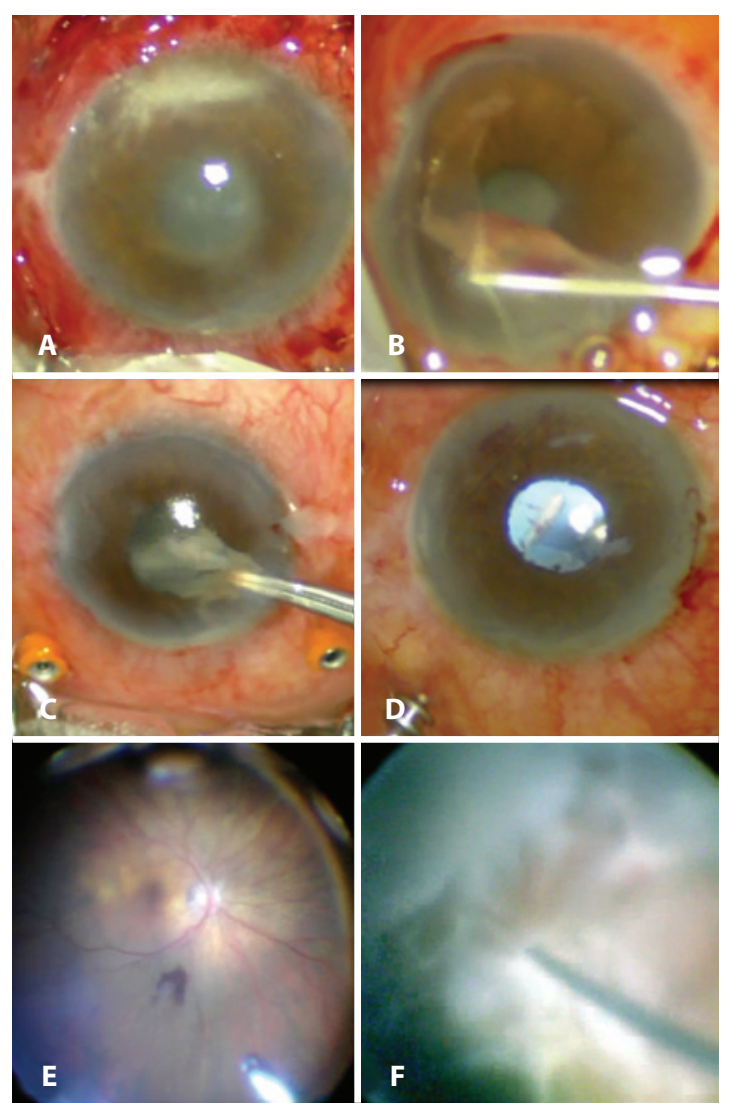

Figure 1. Perioperative images of different patients. A) Appearance before the surgery. B) Mechanical removal of membrane from the anterior chamber. C) Mechanical removal of membrane from the posterior chamber.D) Removal of opacities from the anterior vitreous and posterior capsule. E) Vitrectomy in a mild case. F) Vitrectomy in a severe case.
Vitreous and anterior-chamber fluid aspirates were collected in the operating room using a sterile syringe prior to vitrectomy and intravitreal antibiotic injection and were sent immediately to the microbiology laboratory (at the same hospital) for analysis. A microbiologist inoculated the samples on blood agar, chocolate agar, Macconkey agar and Sabouraud agar.

Following the protocol of the hospital, susceptibility to amikacin, ampicillin, ampicillin sulbactam, aztreonam, cephalothin, cefepime, cefotaxime, cefoxitin, ceftazidime, gentamicin, imipenem, meropenem, piperacillin-tazobactam and trimethoprim-sulfa were tested.

\section{RESULTS}

Forty-five patients (twenty-three men and twenty-two women) presenting acute $P$. aeruginosa endophthalmitis post phacoemulsification were identified. The average age was 71.2 years (range, 56-83 years). The right eye (62\%) was more often affected than the left eye (38\%). Associated systemic medical findings included arterial hypertension (53\%) and type 2 diabetes mellitus (11\%). The median interval between surgery and endophthalmitis onset was 5.5 days (range, 5-6 days).

Visual acuity at diagnosis was better then $20 / 40$ in one patient (2\%), from $20 / 40$ to $20 / 200$ in one patient (2\%), from $20 / 400$ to counting fingers in two patients (4\%), hand movements in eleven patients (24\%) and light perception in thirty patients (68\%). The most significant findings at the diagnosis were decreased visual acuity (96\%), pain (84\%), hyperemia (73\%), eyelid edema (42\%), headache (4\%), foreign body sensation (4\%) and fever (2\%). Additional clinical findings at the diagnosis were conjunctival hyperemia (100\%), anterior chamber inflammatory reaction (91\%), hypopyon (82\%), corneal edema (76\%), pupillary membrane (64\%), chemosis (56\%), vitreous in anterior chamber (4\%), conjunctival purulent secretion (4\%), hyphema (2\%) and shallow anterior chamber (2\%) - table 1.

Cultures were positive for Pseudomonas in twenty-six patients $(57.8 \%)$, three $(6.6 \%)$ anterior chamber samples and twenty-six (57.8\%) vitreous samples. Nineteen patients (42.2\%) had negative cultures. Antibiotic resistance test were similar in all cases, sensitive to amikacin, aztreonam, cefepime, cefotaxime, ceftazidime, gentamicin, imipenem, meropenem, piperacillin-tazobactam and trimetho-

Table 1. The most significant findings at the diagnosis

\begin{tabular}{lc}
\hline Ocular finding & Incidence (\%) \\
\hline Hyperemia & 100 \\
Decreased visual acuity & 96 \\
Anterior chamber reaction & 91 \\
Pain & 84 \\
Hypopyon & 82 \\
Corneal edema & 76 \\
Pupillary membrane & 64 \\
Chemosis & 56 \\
Eyelid edema & 42 \\
Vitreous in anterior chambre & 4 \\
Purulent secretion & 4 \\
Headache & 4 \\
Foreing body sensation & 4 \\
Fever & 2 \\
Hyphema & 2 \\
Shallow anterior chamber & 4 \\
\hline
\end{tabular}


prim-sulfa, and resistant to ampicillin, ampicillin sulbactam, cefoxitin and cephalothin.

One patient (2\%) achieved a final visual acuity better than 20/40; eight patients (18\%) achieved a final visual acuity from 20/40 to 20/200; six patients (13\%) achieved a final visual acuity from 20/400 to counting fingers; eleven patients (25\%) achieved a final acuity of hand movements; thirteen patients (29\%) achieved a final acuity of light perception and six patients (13\%) were no light perception at the last follow-up. Five patients were submitted to a secondary vitrectomy. None of the studied eyes underwent evisceration or enucleation in a three-month follow-up period. Best corrected visual acuity before and after treatment is shown in figure 2 .

\section{DISCUSSION}

The largest Pseudomonas endophthalmitis outbreak post cataract surgery that we were able to find in the literature involved twenty eyes of twenty patients in a six-week period ${ }^{(14)}$. In the current study we had forty-five eyes of forty-five patients (twenty-six culture positive for Pseudomonas) in a two consecutive day period. Endophthalmitis suspect cases cultures turn out to be positive in a range of $24 \%$ to $85 \%$ according to different studies ${ }^{(15)}$.

Pseudomonas aeruginosa is one of the most common Gramnegative pathogens associated with nosocomial infections ${ }^{(14)}$. The epidemics seem to be related to contaminated intraocular irrigating solutions $s^{(6,7,9,12,14)}$. Pseudomonas was also identified in povidone-iodine solution ${ }^{(14)}$, at the fluid pathways of a phacoemulsifier ${ }^{(9)}$, water of autoclave ${ }^{(12)}$ and air-conditioning system ${ }^{(14)}$. Technics as high-resolution fluorescent amplified fragment length polymorphism analysis can identify the source of the outbreak to help preventing new ones ${ }^{(16)}$. It was impossible to identify the source of the outbreak because all the patients were referred from another hospital (500 miles away) and no cultures of the phacoemulsification fluids and ophthalmic solutions were performed.

According to the Endophthalmitis Vitrectomy Study (EVS), the recommended treatment for endophthalmitis is primary vitrectomy only for cases with light perception, any acuity better than this should be submitted to intravitreous antibiotic injection after intraocular fluid aspiration for culture(2). Chen et al., suggests that vitrectomy (primary or secondary) reduces the likelihood of evisceration ${ }^{(17)}$. In the current study all the patients underwent primary vitrectomy, five of them needed a secondary vitrectomy and no patient underwent evisceration or enucleation in a three-month follow-up. The EVS protocol was not followed in this outbreak. The aggressive clinical aspect at the diagnosis of endophthalmitis was crucial for the choice of the treatment performed.

Generally the visual prognosis is poor despite of the treatment with intravitreal antibiotics even in cases in which the isolates

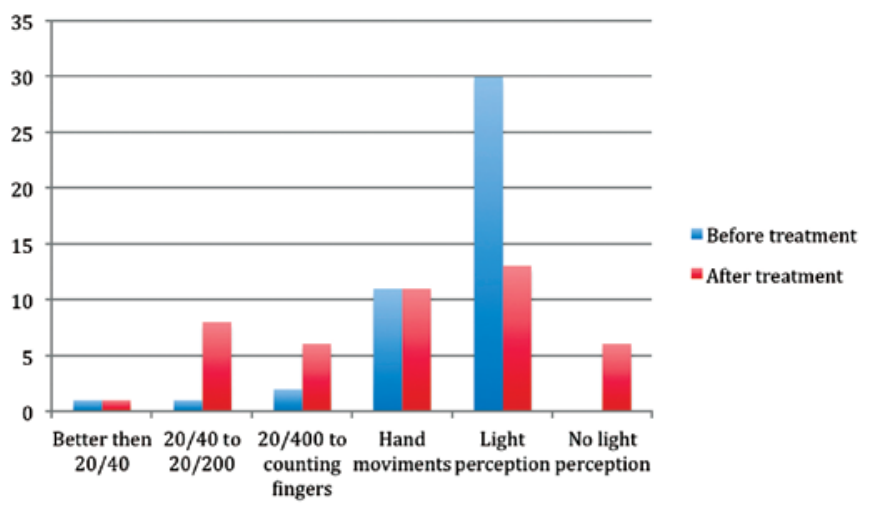

Figure 2. Best corrected visual acuity before and after treatment. were sensitive ${ }^{(14)}$. In a nine patient reported outcome, five of them reached final acuity of no light perception and no patient reached acuity better then 20/400 (4). In the EVS, four of the four hundred and twenty patients had confirmed Pseudomonas endophthalmitis and, three of these, had final acuity worse then $20 / 400^{(2)}$. In the current study, nine patients had final acuity 20/200 or better, six patients between 20/400 and counting fingers, eleven had hand movements, thirteen had light perception and six no light perception. None of these eyes underwent primary or secondary evisceration. Maybe the better visual outcome in some of these cases could be attributed to the treatment performed (primary vitrectomy, anterior chamber irrigation and intravitreal antibiotics) in all patients at the diagnosis despite the visual acuity.

The choice of antibiotics for injection at the first moment, prior to culture results, aims to cover gram positive and gram negative bacteria. The safety and effectiveness of vancomycin and ceftazidime combined has been reported in experimental studies using mice and confirmed in humans case series ${ }^{(4,18)}$. To treat ocular Pseudomonas infection we must take into consideration the increasing prevalence of antibiotic-resistant isolates. Reviewing the literature we have found reports of resistance to various antibiotics as cefazolin, ampicillin, cephalothin, neomycin, chloramphenicol, tetracycline, aminoglycosides, and fluoroquinolones ${ }^{(14)}$. In the current study, resistance to ampicillin, ampicillin-sulbactam, cephalothin and cefoxitin was observed. The other antibiotics tested (amikacin, aztreonam, cefepime, cefotaxime, ceftazidime, gentamicin, imipenem, meropenem, piperacillin-tazobactam and trimethoprim-sulfa) were effective on the isolated strain of Pseudomonas.

\section{CONCLUSION}

Even with all the safety cataract surgery has achieved, today, endophthalmitis remains a risk and a fearful complication of the procedure. The proper cleaning and sterilization of surgical instruments, surgical quality inputs, and correct prophylaxis are crucial to prevention. In the present study, it was impossible to identify the source of the outbreak.

Another fact that caught the attention of the authors was the high level of preservation of the eyeball and some useful vision as compared to the results of other case series found in literature. It might have been due to the early treatment with primary vitrectomy and subsequent intravitreal antibiotic injection at the time of endophthalmitis diagnosis. Further study is needed to sustain this hypothesis.

\section{REFERENCES}

1. Kresloff MS, Castellarin AA, Zarbin MA. Endophthalmitis. Surv Ophthalmol. 1998; 43(3):193-224.

2. Results of the Endophthalmitis Vitrectomy Study. A randomized trial of immediate vitrectomy and of intravenous antibiotics for the treatment of postoperative bacterial endophthalmitis. Endophthalmitis Vitrectomy Study Group. Arch Ophthalmol. 1995;113(12):1479-96. Comment in: Arch Ophthalmol. 1995;113(12):1555-7; Arch Ophthalmol. 1996:114(8):1029-30; Arch Ophthalmol. 1996:114(8):1029; author reply 1028-9, 1030; Arch Ophthalmol. 2002;120(2):231-3; Arch Ophthalmol. 1996;114(8):1025; author reply 1026-7; Arch Ophthalmol. 1996;114(8):1027-8; author reply 1028-9; Arch Ophthalmol. 2002;120(2):230-1.

3. Aaberg TM Jr, Flynn HW Jr, Schiffman J, Newton J. Nosocomial acute-onset postoperative endophthalmitis survey: a 10-year review of incidence and outcomes. Ophthalmology. 1998;105(6):1004-10.

4. Eifrig CW, Scott IU, Flynn HW, Miller D. Endophthalmitis caused by Pseudomonas aeruginosa. Ophthalmology. 2003;110(9):1714-7.

5. Pinna A, Usai D, Sechi LA, Molicotti P, Zanetti s, Carta A. Detection of virulence factors in Pseudomonas aeruginosa strains isolated from contact lens-associated corneal ulcers. Cornea. 2008;27(3):320-6.

6. Swaddiwudhipong W, Tangkitchot T, Silarug N. An outbreak of Pseudomonas aeruginosa postoperative endophthalmitis caused by contaminated intraocular irrigating solution. Trans R Soc Trop Med Hyg. 1995;89(3):288

7. Centers for Disease Control and Prevention (CDC). Outbreaks of postoperative bac- 
terial endophthalmitis caused by intrinsically contaminated ophthalmic solutions - Thailand, 1992, and Canada, 1993. MMWR Morb Mortal Wkly Rep. 1996;45(23): 49-4.

8. Arsan AK, Adisen A, Duman S, Aslan B, Koçak I. Acute endophthalmitis outbreak after cataract surgery. J Cataract Refract Surg. 1996;22(8):1116-20.

9. Zaluski S, Clayman HM, Karsenti G, Bourzeix S, Tournemire A, Faliu B, et al. Pseudomonas aeruginosa endophthalmitis caused by contamination of the internal fluid pathways of a phacoemulsifier. J Cataract Refract Surg. 1999;25(4):540-5.

10. Cruciani M, Malena M, Amalfitano G, Monti P, Bonomi L. Molecular epidemiology in a cluster of cases of postoperative Pseudomonas aeruginosa endophthalmitis. Clin Infect Dis. 1998;26(2):330-3

11. Hoffmann KK, Weber DJ, Gergen MF, Rutala WA, Talte G. Pseudomonas aeruginosa-related postoperative endophthalmitis linked to a contaminated phacoemulsifier. Arch Ophthalmol. 2002;120(1):90-3.

12. Mateos I, Valencia R, Torres MJ, Cantos A, Conde M, Aznar J. Nosocomial outbreak of Pseudomonas aeruginosa endophthalmitis. Infect Control Hosp Epidemiol. 2006; 27(11):1249-51.

13. Boks T, van Dissel JT, Teterissa N, Ros F, Mahmut MH, Utama ED, et al. An outbreak of endophthalmitis after extracapsular cataract surgery probably caused by endotoxin contaminated distilled water used to dissolve acetylcholine. $\mathrm{Br} J$ Ophthalmol. 2006;90(9):1094-7.

14. Pinna A, Usai D, Sechi LA, Zanetti S, Jesudasan NC, Thomas PA, et al. An outbreak of post-cataract surgery endophthalmitis caused by Pseudomonas aeruginosa. Ophthalmology. 2009;116(12):2321-6. Comment in: Ophthalmology. 2010;117(8): 1657-8; author reply 1658-9.

15. Bispo PJ, Melo GB, d'Azevedo PA, Höfling-Lima AL, Yu MC, Pignatari AC. [Culture proven bacterial endophthalmitis: a 6-year review]. Arq Bras Oftalmol. 2008;71(5):617-22. Portuguese.

16. Kenchappa P, Sangwan VS, Ahmed N, Rao KR, Pathengay A, Mathai A, et al. Highresolution genotyping of Pseudomonas aeruginosa strains linked to acute post cataract surgery endophthalmitis outbreaks in India. Ann Clin Microbiol Antimicrob. 2005;4:19.

17. Chen KJ, Sun MH, Lai CC, Wu WC, Chen TL, Kuo YH, et al. Endophthalmitis caused by Pseudomonas aeruginosa in Taiwan. Retina. 2011;31(6):1193-8.

18. Yoshizumi MO, Bhavsar AR, Dessouki A, Kashani A. Safety of repeated intravitreous injections of antibiotics and dexamethasone. Retina. 1999;19(5):437-41. 